\title{
Recognition of Changes in Air and Soil Temperatures at a Station Typical of China's Subtropical Monsoon Region (1961-2018)
}

\author{
Ming-jin Zhan (D), ${ }^{1,2}$ Lingjun Xia, ${ }^{1}$ Longfei Zhan, ${ }^{2}$ and Yuanhao Wang $\mathbb{D}^{3}$ \\ ${ }^{1}$ Jiangxi Provincial Eco-Meteorological Centre, Nanchang 330046, China \\ ${ }^{2}$ Jiangxi Provincial Climate Centre, Nanchang 330046, China \\ ${ }^{3}$ Institute of Atmospheric Physics, Chinese Academy of Sciences, Beijing 100029, China \\ Correspondence should be addressed to Yuanhao Wang; wyhsatan@126.com
}

Received 17 September 2019; Revised 28 October 2019; Accepted 14 November 2019; Published 1 December 2019

Academic Editor: Anthony R. Lupo

Copyright (c) 2019 Ming-jin Zhan et al. This is an open access article distributed under the Creative Commons Attribution License, which permits unrestricted use, distribution, and reproduction in any medium, provided the original work is properly cited.

Trends in soil temperature are important but rarely reported indicators of climate change. Based on daily air and soil temperatures (depth: 0, 20, 80, and $320 \mathrm{~cm}$ ) recorded at the Nanchang Weather Station (1961-2018), this study investigated the variation trend, abrupt changes, and years of anomalous annual and seasonal mean air and soil temperatures. The differences and relationships between annual air and soil temperatures were also analyzed. The results showed close correlations between air temperature and soil temperature at different depths. Annual and seasonal mean air and soil temperatures mainly displayed significant trends of increase over the past 58 years, although the rise of the mean air temperature and the mean soil temperature was asymmetric. The rates of increase in air temperature and soil temperature (depth: 0 , 20, and $80 \mathrm{~cm}$ ) were most obvious in spring; the most significant increase in soil temperature at the depth of $320 \mathrm{~cm}$ was in summer. Mean soil temperature displayed a decreasing trend with increasing soil depth in both spring and summer. Air temperature was lower than the soil temperature at depths of 0 and $20 \mathrm{~cm}$ but higher than the soil temperature at depths of 80 and $320 \mathrm{~cm}$ in spring and summer. Mean ground temperature had a rising trend with increasing soil depth in autumn and winter. Air temperature was lower than the soil temperature at all depths in autumn and winter. Years with anomalously low air temperature and soil temperature at depths of $0,20,80$, and $320 \mathrm{~cm}$ were relatively consistent in winter. Years with anomalous air and soil temperatures (depths: 0,20 , and $80 \mathrm{~cm}$ ) were generally consistent; however, the relationship between air temperature and soil temperature at $320 \mathrm{~cm}$ depth was less consistent. The findings provide a basis for understanding and assessing climate change impact on terrestrial ecosystems.

\section{Introduction}

Increase in global mean surface temperature has been observed over recent centuries. The mean surface temperature around the world has risen by an average of $0.85^{\circ} \mathrm{C}(0.65-$ $1.06^{\circ} \mathrm{C}$ ) from 1880 to 2012 . In the Northern Hemisphere, 1983-2012 might have been the warmest 30-year period of the previous 1400 years [1]. Under the effects of global warming, the mean surface temperature in China has shown a significant warming trend [2]. During 1909-2011, the regional temperature has increased by $0.9-1.5^{\circ} \mathrm{C}$. In the past 50 years (1961-2011), the rate of increase in temperature has been $0.21-0.25^{\circ} \mathrm{C} /$ decade, which is greater than the global average [3].
Soil temperature is one of the factors that have an important impact in relation to climate change. Changes in soil temperature associated with climate warming could result in variation of terrain and hydrologic conditions, alteration of the distribution and growth rate of vegetation, enhancement of soil organic carbon decomposition, and increased emission of $\mathrm{CO}_{2}$ from the soil to the atmosphere [4-8]. These effects could have significant consequences both locally and globally. However, because of the lack of observations with adequate spatial and/or temporal coverage, soil temperatures have not been analyzed as comprehensively as other climatic factors such as air temperature and precipitation. In the past century, the rate of warming of soil temperature in Ireland has reached $0.04-0.25^{\circ} \mathrm{C} /$ decade [9]. 
During 1958-2008, soil temperature showed a trend of increase of $0.26-0.30^{\circ} \mathrm{C} /$ decade in spring at approximately two-thirds of the monitoring stations in Canada [10]. Permafrost temperatures along a transect from north to south across Alaska generally warmed from the late 1980s to 1996. The magnitude of permafrost warming has been estimated in the range of $0.5-1.5^{\circ} \mathrm{C}$ [11]. In Russia, soil temperature at depths of $40-320 \mathrm{~cm}$ have increased by up to $9^{\circ} \mathrm{C}$ during winter, while air temperature has increased by approximately $4-6^{\circ} \mathrm{C}[12]$. In Lhasa (Tibet), seasonal mean soil temperatures at depths below $40 \mathrm{~cm}$ have shown an even greater trend $\left(0.43-0.66^{\circ} \mathrm{C} /\right.$ decade $)$ than air temperature [13]. Based on analysis of the long-term changes (1961-2010) in soil temperature at Guilin (southern China), Chen and Zhou [14] found that the annual variation of air temperature correlated very well with soil temperatures (below the depth of $80 \mathrm{~cm}$ ). The rate of increase and the range of annual mean air temperature were reported as $0.184^{\circ} \mathrm{C} /$ decade and $0.8^{\circ} \mathrm{C}$, respectively, i.e., higher than the changes of annual mean ground temperature at depths of $5-80 \mathrm{~cm}$.

Many studies have investigated the variations of air and soil temperatures, but examination of the relationship between the changes of air temperature and soil temperature remains largely comparative. The question of whether there are regional differences between air and soil temperatures and the reasons for such differences remain unclear. This restricts accurate assessment of the impact of climate change on terrestrial ecosystems. In this study, the Nanchang Weather Station, located in a subtropical monsoon region of China that is sensitive to climate change, was adopted as the research object. The trends of variation of air temperature and soil temperature at four depths $(0,20,80$, and $320 \mathrm{~cm})$ over the period 1960-2018 were investigated. The overall variation, abrupt changes, abnormal years of temperature, and the relationship between air and soil temperatures were analyzed. The research results will provide a scientific basis for improved understanding and assessment of the impact of climate change on terrestrial ecosystems.

\section{Data and Methods}

2.1. Study Area. The Nanchang National Weather Station $\left(28^{\circ} 36^{\prime} \mathrm{N}, 115^{\circ} 55^{\prime} \mathrm{E}\right.$; elevation: $\left.46.9 \mathrm{~m}\right)$ is located in the Poyang Lake Basin of the middle-lower reaches of the Yangtze River, China (Figure 1). The annual temperature at the Nanchang Weather Station is $18^{\circ} \mathrm{C}$, and annual precipitation is approximately $1600 \mathrm{~mm}$. The region has four distinct seasons: spring (March-May), summer (JuneAugust), autumn (September-November), and winter (December-February). The main reason for choosing the Nanchang Weather Station as the research object is that the station has remained at the same location since 1960. Moreover, the time series data of both air temperature and soil temperatures at various depths recorded at the station are long and the data integrity is considered satisfactory (i.e., amount of missing data annually is $<5 \%$ ). In this study, the seasonal, interannual, and interdecadal variations of air temperature and soil temperatures (at depths of $0,20,80$,

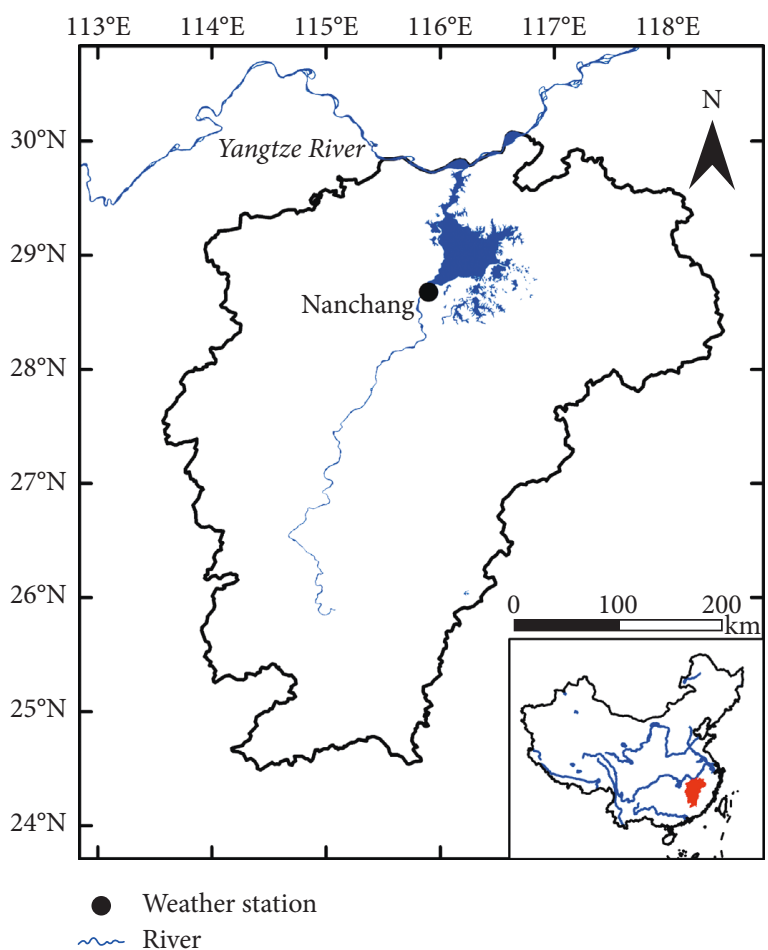

FIgURE 1: Location of the Nanchang National Weather Station, China.

and $320 \mathrm{~cm}$ ) at the Nanchang Weather Station were analyzed.

2.2. Data Description. The records of both daily air temperature and soil temperature measured at the Nanchang Weather Station extend from January 1, 1960, to December 31,2018 . The amount of missing data during the 59-year period (i.e., $<1 \%$ ) is considered to have had little or no effect on the integrity of the research results.

\subsection{Method}

2.3.1. Test of Abrupt Change. An accumulative anomaly curve can be used to indicate a sudden change in temperature:

$$
C(t)=\sum_{i=1}^{t}\left(X_{i}-\bar{X}\right),
$$

where $C(t)$ is the accumulative anomaly of temperature, $X_{i}$ is the value of the $i$-th year, and $\bar{X}$ is the mean value of the series. When the accumulative anomaly value $C(t)$ reaches the maximum, the corresponding $t$ is the year of the turning point. To test whether the turning point meets the criterion of abrupt change, the signal-to-noise ratio (SNR) of the turning year is calculated:

$$
\frac{S}{N}=\frac{\left|\overline{X_{1}}-\overline{X_{2}}\right|}{S_{1}+S_{2}}
$$


where $S / N$ is the SNR of the turning year, $\overline{X_{1}}$ and $\overline{X_{2}}$ are the mean values of the stage before and the stage after the turning year, respectively, and $S_{1}$ and $S_{2}$ are the respective standard deviations of those two stages. When the value of $S / N$ is $>1.0$, the existence of an abrupt change is indicated $[15,16]$.

2.3.2. Anomaly and Standard Deviation. Climate anomalies are considered conditions in which anomalies of climatic elements reach a certain magnitude. The World Meteorological Organization believes that when an anomaly of a climatic element is more than double the standard deviation, the climatic element should be considered abnormal.

\section{Results}

3.1. Relationship between Annual Mean Air Temperature and Soil Temperature. Since 1960, both the annual mean air temperature and the annual mean soil temperature at different layers at the Nanchang Weather Station have been increasing. Over this period, the annual mean air temperature has remained lower than all the annual mean soil temperatures. The temperature difference between the air and the ground is positive. It is because the surface heating of the atmosphere is greater than the cooling effect, which means the transfer of heat to the atmosphere is dominant in Nanchang (Figure 2).

Based on data from 1960-2018, the correlation coefficient $(R)$ of the linear relationship between the annual air temperature and the annual $0 \mathrm{~cm}$ soil temperature was determined as $0.914(P<0.01$, Figure 3$)$. The correlation coefficients between the annual air temperature and the annual soil temperature at the different layers studied $(0,20$, 80 , and $320 \mathrm{~cm}$ ) in the past 58 years were all $>0.700$, and they all passed the 0.01 significance test (Table 1 ). This finding indicates that the trends of air and soil temperatures have reasonable consistency.

3.2. Interdecadal Changes of Air Temperature and Soil Temperatures. In the past 58 years, the air temperature has increased significantly at the Nanchang Weather Station $(P<0.01)$. The interdecadal mean air temperature in the 2010 s, which was the warmest decade of the past 58 years, was $0.8^{\circ} \mathrm{C}$ higher than the annual mean air temperature during 1961-2018. The interdecadal mean air temperature in the $1960 \mathrm{~s}, 1970 \mathrm{~s}$, and $1980 \mathrm{~s}$ was $0.2,0.5$, and $0.5^{\circ} \mathrm{C}$ lower, respectively, than the annual mean air temperature. In the $1990 \mathrm{~s}(2000 \mathrm{~s})$, it was equivalent to $\left(0.6^{\circ} \mathrm{C}\right.$ higher than $)$ the annual mean air temperature (Table 2).

During 1961-2018, the air temperature increased by $1.0^{\circ} \mathrm{C}$, although the rate of change varied between the different decades. From the 1960s to the 1970s, the air temperature dropped by $0.3^{\circ} \mathrm{C}$; in the $1970 \mathrm{~s}$ and $1980 \mathrm{~s}$, the temperature remained largely unchanged, and after the $1990 \mathrm{~s}$, the temperature increased obviously. It has increased by $0.5^{\circ} \mathrm{C}$ from the $1980 \mathrm{~s}$ to the $1990 \mathrm{~s}$. After the $2000 \mathrm{~s}$, the temperature has been increasing, rising by $0.6^{\circ} \mathrm{C}\left(0.2^{\circ} \mathrm{C}\right)$ from the 1990 s to the 2000s (from the 2000s to the 2010s).
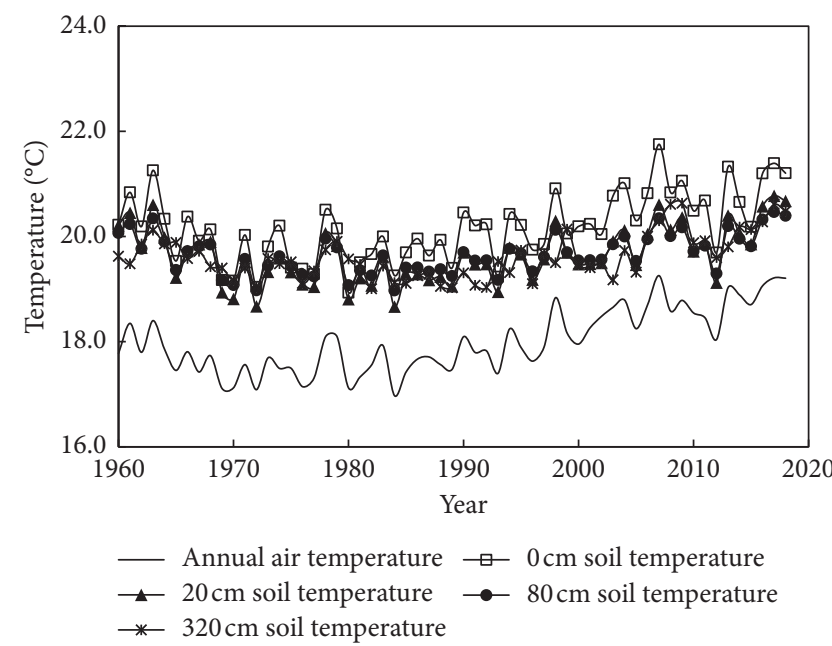

FIgURE 2: Changes of annual mean air and soil temperatures at the Nanchang Weather Station.

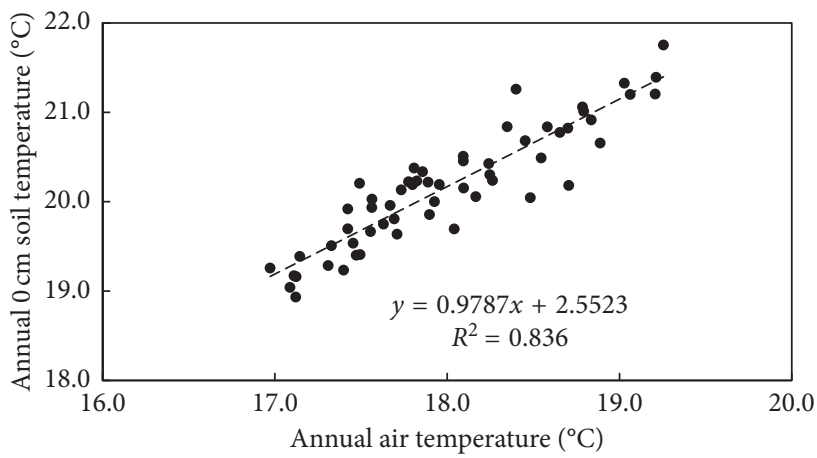

FIgURE 3: Relationship between annual mean air temperature and annual mean soil temperature at $0 \mathrm{~cm}$ depth at the Nanchang Weather Station.

TABLE 1: Relationship between annual mean air and soil temperatures.

\begin{tabular}{lcc}
\hline Soil depth $(\mathrm{cm})$ & Regression equation & Correlation coefficient \\
\hline 0 & $y=0.9787 x+2.5523$ & 0.914 \\
20 & $y=0.748 x+6.181$ & 0.858 \\
80 & $y=0.529 x+10.147$ & 0.798 \\
320 & $y=0.4908 x+10.785$ & 0.700 \\
\hline
\end{tabular}

Note. $x$ : annual mean air temperature $\left({ }^{\circ} \mathrm{C}\right) ; y$ : annual mean soil temperature $\left({ }^{\circ} \mathrm{C}\right)$.

The soil temperatures at different layers have increased significantly since $1960(P<0.01)$, although the rates of change varied between the different decades. Soil temperatures exhibited a cooling trend from the 1960s to the 1970s, following which they remained stable from the 1970s to the $1980 \mathrm{~s}$. The mean soil temperatures were $0.2-0.5^{\circ} \mathrm{C}$ lower than the annual mean temperature over the 60 -year period. Since the 1990s, the soil temperatures have risen rapidly. In the 2010s, the warmest decade, the soil temperatures were $0.5-0.6^{\circ} \mathrm{C}$ higher than the annual mean soil temperatures of 
TABLE 2: Interdecadal mean air and soil temperatures, annual mean air and soil temperatures in the past 58 years, and the rate of climatic trend of annual mean temperatures $\left({ }^{\circ} \mathrm{C} /\right.$ decade) at the Nanchang Weather Station.

\begin{tabular}{|c|c|c|c|c|c|c|c|c|}
\hline \multirow{2}{*}{ Index } & \multicolumn{6}{|c|}{ Interdecadal mean temperature $\left({ }^{\circ} \mathrm{C}\right)$} & \multirow{2}{*}{ Annual mean temperature $\left({ }^{\circ} \mathrm{C}\right)$} & \multirow{2}{*}{ Climatic trend rate $\left({ }^{\circ} \mathrm{C} /\right.$ decade $)$} \\
\hline & $1960 s$ & 1970s & 1980s & 1990s & $2000 s$ & $2010 \mathrm{~s}$ & & \\
\hline Air temperature & 17.8 & 17.5 & 17.5 & 18.0 & 18.6 & 18.8 & 18.0 & 0.255 \\
\hline $0 \mathrm{~cm}$ soil temperature & 20.2 & 19.7 & 19.6 & 20.1 & 20.7 & 20.8 & 20.2 & 0.186 \\
\hline $20 \mathrm{~cm}$ soil temperature & 19.9 & 19.3 & 19.1 & 19.6 & 19.9 & 20.1 & 19.6 & 0.104 \\
\hline $80 \mathrm{~cm}$ soil temperature & 19.8 & 19.4 & 19.3 & 19.6 & 19.9 & 20.0 & 19.7 & 0.074 \\
\hline $320 \mathrm{~cm}$ soil temperature & 19.7 & 19.4 & 19.2 & 19.4 & 19.8 & 20.1 & 19.6 & 0.104 \\
\hline
\end{tabular}

the different layers. Since 1960, the soil temperatures have increased by $0.2-0.6^{\circ} \mathrm{C}$ at different depths.

In the past 58 years, the annual air temperature was $18.0^{\circ} \mathrm{C}$, which is lower than the annual soil temperatures by $1.6-2.2^{\circ} \mathrm{C}$. However, the rate of increase and the range of air temperatures were $0.255^{\circ} \mathrm{C} /$ decade and $1.0^{\circ} \mathrm{C}$, respectively, i.e., higher than all soil temperatures (equivalent rate of increase and range of $0.104-0.186^{\circ} \mathrm{C} /$ decade and $0.2-0.6^{\circ} \mathrm{C}$, respectively). Overall, the response of air temperature to the effects of global warming during the study period has been much faster and stronger than that of soil temperatures. It is evident that there has been asymmetry in the warming of air and soil temperatures.

\subsection{Seasonal Changes in Air Temperature and Soil Temperatures.} In the past 58 years, the seasonal air temperature and soil temperatures have generally warmed, although the soil temperatures at depths of 0,20 , and $80 \mathrm{~cm}$ in summer and at the depth of $320 \mathrm{~cm}$ in winter show a slight decrease (Table 3).

In comparison with the annual mean air temperature during 1960-2018, the spring, summer, and autumn air temperatures in the $2010 \mathrm{~s}$ increased by $0.9,0.5$, and $0.8^{\circ} \mathrm{C}$, respectively. The 2010s was the warmest decade of the past 58 years, except during winter. The warmest winter during the study period was in the 2000s, when the mean temperature was $0.7^{\circ} \mathrm{C}$ higher than the 60 -year average. From the 1960 s to the 2010s, the average seasonal temperatures in spring, summer, autumn, and winter have increased by 1.5, 0.4, 0.9, and $1.0^{\circ} \mathrm{C}$, respectively.

The interdecadal variations of soil temperatures in spring and autumn were similar to air temperature. The decade of warmest soil temperatures at all studied depths in spring and autumn was the 2010s, and the decade of warmest winter soil temperatures was the 2000 s, i.e., the same as air temperature. The highest soil temperatures at depths of 0,20 , and $80 \mathrm{~cm}$ in summer were in the 1960s, while the highest soil temperature at the depth of $320 \mathrm{~cm}$ was in the 2010s.

The rate of increase in air temperature and soil temperatures at depths of 0,20 , and $80 \mathrm{~cm}$ was fastest in spring, i.e., $0.371,0.380,0.295$, and $0.202^{\circ} \mathrm{C} /$ decade, respectively. The fastest rate of increase of soil temperature at depth of $320 \mathrm{~cm}$ $\left(0.145^{\circ} \mathrm{C} /\right.$ decade $)$ was in summer.

In spring and summer, soil temperature decreases with increasing soil depth. In spring and summer, the air temperature was cooler than the soil temperatures at depths of 0 and $20 \mathrm{~cm}\left(0.4-4.0^{\circ} \mathrm{C}\right)$ but warmer than the soil temperatures at depths of 80 and $320 \mathrm{~cm}\left(1.0-7.7^{\circ} \mathrm{C}\right)$. The rate of increase of air temperature was $0.371^{\circ} \mathrm{C} /$ decade in spring, which was less than the rate of increase of soil temperature at depth of $0 \mathrm{~cm}\left(0.380^{\circ} \mathrm{C} /\right.$ decade $)$ but greater than the rate of increase at other soil depths (0.135$0.295^{\circ} \mathrm{C} /$ decade). The rate of increase of air temperature was $0.083^{\circ} \mathrm{C} /$ decade in summer, which was greater than the rate of increase of soil temperature at depths of 0,20 , and $80 \mathrm{~cm}\left(-0.048\right.$ to $0.091^{\circ} \mathrm{C} /$ decade $)$ but less than the rate of increase of soil temperature at depth of $320 \mathrm{~cm}\left(0.145^{\circ} \mathrm{C} /\right.$ decade). In autumn and winter, soil temperature increases with increasing soil depth. In autumn and winter, the air temperature was cooler than the soil temperatures at all depths $\left(0.7-11.9^{\circ} \mathrm{C}\right)$. The rate of increase of air temperature was $0.259^{\circ} \mathrm{C} /$ decade in autumn and $0.273^{\circ} \mathrm{C} /$ decade in winter, i.e., greater than the rate of increase of all soil temperatures $\left(-0.072\right.$ to $0.240^{\circ} \mathrm{C} /$ decade). In general, in the past 58 years, the rate of increase of seasonal air temperature has been greater than the rate of increase of soil temperature at all depths except the $0 \mathrm{~cm}$ depth. It means the response of air temperature to the effects of global warming during the study period has been faster and stronger than that of soil temperatures.

3.4. Variation of the Difference between Air Temperature and Soil Temperatures. Over the past 58 years, the differences between air temperature and the soil temperatures at different depths at the Nanchang Weather Station have shown a trend of decrease, mainly because the rate of warming of air temperature has been greater than that of soil (Figure 4). The difference between the soil temperature at $0 \mathrm{~cm}$ depth and the air temperature has remained relatively stable, although it has declined by $0.4^{\circ} \mathrm{C}$ since 1960 . The difference between the soil temperature at $20 \mathrm{~cm}$ depth and the air temperature has had two significant periods of decline (the 1960s-1970s and the 1990s-2000s), and it has reduced by $0.8^{\circ} \mathrm{C}$ over the past 58 years. The difference between the soil temperature at $80 \mathrm{~cm}$ depth and the air temperature showed a trend similar to that at $20 \mathrm{~cm}$ depth, with a reduction over the study period of $0.9^{\circ} \mathrm{C}$. The difference between the soil temperature at $320 \mathrm{~cm}$ depth and the air temperature remained relatively stable from the 1960 s to the 1970 s, although it has declined steadily since the 1980s. Overall, the temperature difference has decreased by $0.7^{\circ} \mathrm{C}$ since 1960 . The rates of climatic trend between the air temperature and the soil temperatures at depths of 0,20 , and $320 \mathrm{~cm}$ range from -0.069 to $-0.181^{\circ} \mathrm{C} /$ 
TABLE 3: Interdecadal seasonal mean air and soil temperatures $\left({ }^{\circ} \mathrm{C}\right)$, seasonal mean air and soil temperatures in the recent 58 years $\left({ }^{\circ} \mathrm{C}\right)$, and the rate of climatic trend of seasonal mean temperatures $\left({ }^{\circ} \mathrm{C} /\right.$ decade) at the Nanchang Weather Station.

\begin{tabular}{|c|c|c|c|c|c|c|}
\hline Season & Interdecadal & $\begin{array}{c}\text { Mean air } \\
\text { temperature }\end{array}$ & $\begin{array}{c}0 \mathrm{~cm} \text { soil } \\
\text { temperature }\end{array}$ & $\begin{array}{c}20 \mathrm{~cm} \text { soil } \\
\text { temperature }\end{array}$ & $\begin{array}{c}80 \mathrm{~cm} \text { soil } \\
\text { temperature }\end{array}$ & $\begin{array}{l}320 \mathrm{~cm} \text { soil } \\
\text { temperature }\end{array}$ \\
\hline \multirow{8}{*}{ Spring } & $1960 s$ & 16.9 & 18.7 & 17.6 & 16.5 & 16.3 \\
\hline & 1970 s & 16.5 & 18.0 & 17.0 & 16.1 & 16.1 \\
\hline & $1980 \mathrm{~s}$ & 16.6 & 18.2 & 16.9 & 16.1 & 15.9 \\
\hline & $1990 \mathrm{~s}$ & 17.1 & 18.8 & 17.6 & 16.5 & 16.2 \\
\hline & $2000 s$ & 18.1 & 19.8 & 18.4 & 17.1 & 16.6 \\
\hline & 2010 s & 18.4 & 20.0 & 18.6 & 17.2 & 16.8 \\
\hline & Annual & 17.3 & 18.9 & 17.7 & 16.6 & 16.3 \\
\hline & $\begin{array}{c}\text { Climatic trend } \\
\text { rate }\end{array}$ & 0.371 & 0.380 & 0.295 & 0.202 & 0.135 \\
\hline \multirow{8}{*}{ Summer } & $1960 \mathrm{~s}$ & 28.3 & 32.7 & 30.2 & 27.0 & 20.4 \\
\hline & 1970 s & 28.0 & 32.0 & 29.7 & 26.8 & 20.3 \\
\hline & $1980 s$ & 27.9 & 32.0 & 29.4 & 26.6 & 20.0 \\
\hline & 1990s & 27.8 & 31.7 & 29.2 & 26.5 & 20.2 \\
\hline & $2000 s$ & 28.5 & 32.4 & 29.6 & 26.7 & 20.7 \\
\hline & 2010 s & 28.7 & 32.2 & 29.7 & 26.8 & 21.1 \\
\hline & Annual & 28.2 & 32.2 & 29.6 & 26.7 & 20.5 \\
\hline & $\begin{array}{l}\text { Climatic trend } \\
\text { rate }\end{array}$ & 0.083 & -0.088 & -0.091 & -0.048 & 0.145 \\
\hline \multirow{8}{*}{ Autumn } & $1960 \mathrm{~s}$ & 19.4 & 21.9 & 22.4 & 23.3 & 23.0 \\
\hline & 1970 s & 18.8 & 21.1 & 21.6 & 22.8 & 22.7 \\
\hline & 1980 s & 19.0 & 21.0 & 21.4 & 22.7 & 22.3 \\
\hline & $1990 s$ & 19.6 & 21.9 & 22.0 & 23.1 & 22.5 \\
\hline & $2000 s$ & 20.1 & 22.5 & 22.2 & 23.2 & 22.9 \\
\hline & 2010 s & 20.3 & 22.5 & 22.4 & 23.3 & 23.3 \\
\hline & Annual & 19.5 & 21.8 & 22.0 & 23.1 & 22.8 \\
\hline & $\begin{array}{l}\text { Climatic trend } \\
\text { rate }\end{array}$ & 0.259 & 0.240 & 0.092 & 0.056 & 0.062 \\
\hline \multirow{8}{*}{ Winter } & $1960 \mathrm{~s}$ & 6.1 & 7.1 & 8.9 & 12.2 & 19.0 \\
\hline & 1970 s & 6.5 & 7.4 & 8.8 & 12.1 & 18.8 \\
\hline & $1980 \mathrm{~s}$ & 6.3 & 7.1 & 8.6 & 12.1 & 18.6 \\
\hline & 1990 s & 7.3 & 7.9 & 9.3 & 12.4 & 18.9 \\
\hline & $2000 s$ & 7.5 & 8.1 & 9.3 & 12.4 & 19.1 \\
\hline & 2010 s & 7.1 & 7.6 & 8.9 & 12.2 & 18.0 \\
\hline & Annual & 6.8 & 7.5 & 9.0 & 12.2 & 18.7 \\
\hline & $\begin{array}{l}\text { Climatic trend } \\
\text { rate }\end{array}$ & 0.273 & 0.185 & 0.092 & 0.051 & -0.072 \\
\hline
\end{tabular}

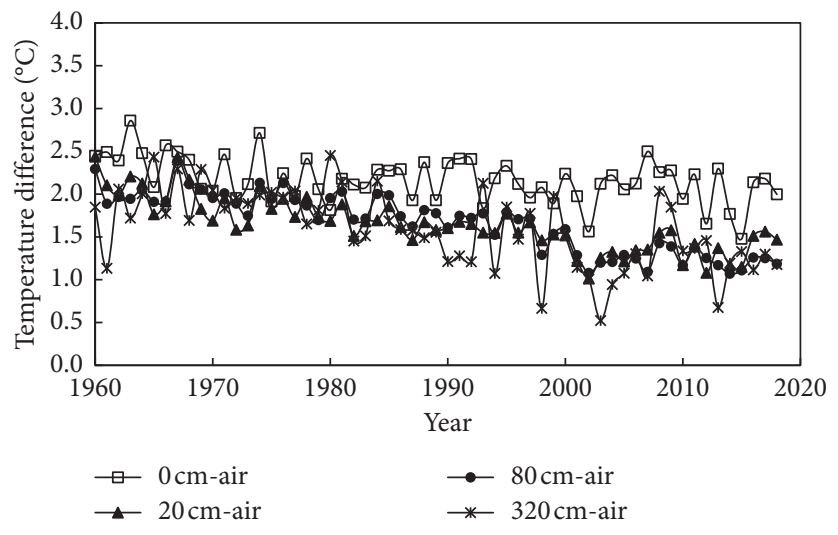

FIgURE 4: Change of difference between annual mean soil temperature and air temperature at the Nanchang Weather Station. 
TABLE 4: Interdecadal difference between mean soil temperature and air temperature, annual mean temperature difference in recent 58 years, and the rate of climatic trend of annual mean temperature difference at the Nanchang Weather Station.

\begin{tabular}{lcccccccc}
\hline \multirow{2}{*}{ Index } & \multicolumn{9}{c}{ Interdecadal } & \multicolumn{2}{c}{ Annual mean } & \multirow{2}{*}{ Climatic trend rate } \\
\hline $0 \mathrm{~cm}$ air & $1960 \mathrm{~s}$ & $1970 \mathrm{~s}$ & $1980 \mathrm{~s}$ & $1990 \mathrm{~s}$ & $2000 \mathrm{~s}$ & $2010 \mathrm{~s}$ & 2.2 & -0.069 \\
$20 \mathrm{~cm}$ air & 2.4 & 2.2 & 2.1 & 2.2 & 2.1 & 2.0 & 1.6 & -0.151 \\
$80 \mathrm{~cm}$ air & 2.1 & 1.8 & 1.7 & 1.6 & 1.3 & 1.3 & 1.7 & -0.181 \\
$320 \mathrm{~cm}$ air & 1.9 & 1.9 & 1.8 & 1.6 & 1.3 & 1.2 & 1.6 & -0.152 \\
\hline
\end{tabular}

decade (Table 4). The rate of decrease of the temperature difference increases with increasing soil depth, i.e., the greater the depth of soil, the larger the reduction of the temperature difference.

\subsection{Abrupt Change and Anomalous Characteristics of Air and} Soil Temperatures. Based on equations (1) and (2), the years of abrupt change in air and soil temperatures were calculated. An abrupt change of annual mean air temperature occurred in 1997, while the abrupt change of spring air temperature occurred in 1996. Abrupt changes of summer and annual soil temperature at the depth of $320 \mathrm{~cm} \mathrm{oc-}$ curred in 2005. Most annual and seasonal air and soil temperatures did not show abrupt changes; however, in general, the air and soil temperatures have changed from a relatively cold period to a comparatively warm period (Table 5).

In spring, the soil temperatures at depths of 20 and $80 \mathrm{~cm}$ were abnormally low in 1970. In 2007 and 2009, the soil temperature at $320 \mathrm{~cm}$ depth was abnormally high. In 2008 , both the air temperature and the soil temperature at $0 \mathrm{~cm}$ depth were abnormally high. The air temperature and the soil temperatures at all depths were abnormally high in 2018. In summer, the air temperature and soil temperatures at depths of 0,20 , and $80 \mathrm{~cm}$ were abnormally low in 1999. The soil temperatures at the depths of 0,20 , and $80 \mathrm{~cm}$ were abnormally high in 1961, while the soil temperature at $320 \mathrm{~cm}$ depth was abnormally high in both 2008 and 2018. In 2013, the air temperature was abnormally high. In autumn, the air temperature and soil temperature at $0 \mathrm{~cm}$ depth were abnormally low in 1976 and 1981; the soil temperatures at depths of 20 and $80 \mathrm{~cm}$ were also abnormally low in 1981. Air temperature was abnormally high in 2014, and the soil temperature at the depth of $320 \mathrm{~cm}$ was abnormally high in both 2008 and 2009. In winter, air temperature and soil temperatures at all depths were abnormally (high) low in 2012 (2016). In terms of the annual mean, air temperature and soil temperature at the depth of $0 \mathrm{~cm}$ were abnormally high in 2007. Soil temperatures at depths of 20 and $80 \mathrm{~cm}(320 \mathrm{~cm})$ were abnormally high in 2017 (2008, 2009, 2017, and 2018). Comparison revealed consistency between the years of abnormal air temperature and soil temperature at $0 \mathrm{~cm}$ depth. The years of abnormal seasonal temperature at depths of 0,20 , and $80 \mathrm{~cm}$ were also consistent, while the years of abnormal annual temperature differed. The soil temperature at depth of $320 \mathrm{~cm}$ was not consistent with other temperatures in abnormal years (Table 6).
TABLE 5: Abrupt change years of annual and seasonal mean air and soil temperatures at the Nanchang Weather Station.

\begin{tabular}{lccccc}
\hline Index & Spring & Summer & Autumn & Winter & Annual \\
\hline Air temperature & 1996 & - & - & - & 1997 \\
$0 \mathrm{~cm}$ temperature & - & - & - & - & - \\
$20 \mathrm{~cm}$ temperature & - & - & - & - & - \\
$80 \mathrm{~cm}$ temperature & - & - & - & - & - \\
$320 \mathrm{~cm}$ & - & 2005 & - & - & 2005 \\
temperature & & & & & \\
\hline
\end{tabular}

Note. “-" indicates no abrupt change.

TABLE 6: Years of anomalous annual and seasonal mean air and soil temperatures at the Nanchang Weather Station.

\begin{tabular}{|c|c|c|c|c|c|}
\hline Index & Spring & Summer & Autumn & Winter & Annual \\
\hline $\begin{array}{l}\text { Air } \\
\text { temperature }\end{array}$ & $\begin{array}{c}2008 \\
2018(+)\end{array}$ & $\begin{array}{l}2013 \\
(+), \\
1999 \\
(-)\end{array}$ & $\begin{array}{c}2014(+), \\
1976, \\
1981(-)\end{array}$ & $\begin{array}{l}2016 \\
(+), \\
2012 \\
(-)\end{array}$ & $2007(+)$ \\
\hline $\begin{array}{l}0 \mathrm{~cm} \\
\text { temperature }\end{array}$ & $\begin{array}{c}2008, \\
2018(+)\end{array}$ & $\begin{array}{c}1961 \\
(+), \\
1999 \\
(-)\end{array}$ & $\begin{array}{c}1976, \\
1981(-)\end{array}$ & $\begin{array}{l}2016 \\
(+), \\
2012 \\
(-)\end{array}$ & $2007(+)$ \\
\hline $\begin{array}{l}20 \mathrm{~cm} \\
\text { temperature }\end{array}$ & $\begin{array}{l}2018(+) \\
1970(-)\end{array}$ & $\begin{array}{l}1961 \\
(+), \\
1999 \\
(-)\end{array}$ & $1981(-)$ & $\begin{array}{l}2016 \\
(+), \\
2012 \\
(-)\end{array}$ & $2017(+)$ \\
\hline $\begin{array}{l}80 \mathrm{~cm} \\
\text { temperature }\end{array}$ & $\begin{array}{l}2018(+) \\
1970(-)\end{array}$ & $\begin{array}{l}1961 \\
(+), \\
1999 \\
(-)\end{array}$ & $1981(-)$ & $\begin{array}{l}2016 \\
(+), \\
2012 \\
(-)\end{array}$ & $2017(+)$ \\
\hline $\begin{array}{l}320 \mathrm{~cm} \\
\text { temperature }\end{array}$ & $\begin{array}{c}2007, \\
2009, \\
2017,2018 \\
(+)\end{array}$ & $\begin{array}{c}2008, \\
2018(+)\end{array}$ & $\begin{array}{c}2008 \\
2009(+)\end{array}$ & $\begin{array}{l}2012 \\
(-)\end{array}$ & $\begin{array}{c}2008, \\
2009, \\
2017, \\
2018 \\
(+)\end{array}$ \\
\hline
\end{tabular}

Note. (+), abnormally high; (-), abnormally low.

\section{Conclusions and Discussion}

Over the past century, the global temperature has undergone significant change in terms of warming, and this change has shown an increasing trend in recent years because of the combined effects of human activities and natural factors $[1,17]$. The effects of global warming affect not only air temperature but also precipitation patterns and soil temperature [18]. Soil temperature is one of the main factors affecting plant growth through control of biogeochemical 
processes such as dissolved organic carbon export [19], length of growing season $[20,21]$, rates of mineralization $[22,23]$, nutrient assimilation by plants [24, 25], and plant productivity [26]. Under the background of global warming, it is very important to research the variation of soil temperature and its relationship with air temperature. Such work can provide theoretical support for the development of reasonable measures for the adaptation of agricultural practices to the effects of climate change. This study found that seasonal and annual air and soil temperatures at the study site have had significant upward trends over the past 58 years, consistent with previous research results [27-30]. However, this study also found that the rates and magnitudes of the warming of air and soil temperatures are inconsistent; i.e., there has been asymmetry in temperature rise. Existing research has indicated that the difference between soil temperatures and the air temperature in most of China is positive. In the arid regions of Northwest China, the temperature difference in autumn and winter show a decreasing trend, while in other seasons, the temperature difference shows an upward trend [31,32]. In the humid regions of South China, the annual and seasonal temperature differences between air and soil temperatures show a decreasing trend [14]. In different regions, the abrupt change years and years of abnormal air and soil temperatures are also different. Therefore, the inconsistency found between the soil and air temperatures at the Nanchang Weather Station could lead to large errors when assessing the impact of climate change on terrestrial ecosystems using only air temperature data. As the Nanchang site is located in the subtropical monsoon region of China, further work will be required to determine whether the changes of the trends of soil and air temperatures observed in this study are exhibited in regions with other climate types.

Based on daily temperature data, this study analyzed the variation of seasonal and annual temperature, probability distribution of temperature in different climatic states, relationship between air and soil temperatures, difference between soil and air temperatures, and abrupt changes and abnormal years. The main conclusions derived are as follows:

(1) The relationships between the air temperature and soil temperature at each of the studied depths over the past 58 years all showed good correlation and a significant upward trend. The annual air temperature was lower than the soil temperature by $1.6-2.2^{\circ} \mathrm{C}$, but both the rate $\left(0.255^{\circ} \mathrm{C} /\right.$ decade $)$ and the range $\left(1.0^{\circ} \mathrm{C}\right)$ of warming of the air temperature were larger than those of soil temperature at all depths. Under the background of global warming, the change of air temperature has been faster and more intense than soil temperature. The rate of increase of air and soil temperatures has been asymmetric.

(2) Annual and seasonal air and soil temperatures have mostly increased over the study period. However, soil temperatures at depths of 0,20 , and $80 \mathrm{~cm}$ in summer and at $320 \mathrm{~cm}$ depth in winter showed slight decreasing trends. Air temperature and soil temperatures at depths of 0,20 , and $80 \mathrm{~cm}$ had the highest warming rates in spring, while soil temperature at $320 \mathrm{~cm}$ depth had the highest warming rate in summer. The rate of increase of air temperature and soil temperature at depths of 0,20 , and $80 \mathrm{~cm}$ were most obvious in spring, i.e., rates of $0.371,0.380,0.295$, and $0.202^{\circ} \mathrm{C} /$ decade, respectively. The rate of increase of soil temperature at $320 \mathrm{~cm}$ depth $\left(0.145^{\circ} \mathrm{C} /\right.$ decade $)$ was most obvious in summer. In both spring and summer, the soil temperature decreases with increasing depth. The air temperature is lower than the soil temperature at depths of 0 and $20 \mathrm{~cm}$ but higher than the soil temperature at depths of 80 and $320 \mathrm{~cm}$. In autumn and winter, the soil temperature increases with increasing depth, and the air temperature is lower than the soil temperature at each depth.

(3) Over time, the differences between the air temperature and soil temperatures at different depths decreased, reducing by $0.4-0.9^{\circ} \mathrm{C}$. The rates of the climatic trend of the differences between the air temperature and soil temperatures were between -0.069 and $-0.181^{\circ} \mathrm{C} /$ decade, and the rate of reduction increased with increasing soil depth.

(4) Generally, the air and soil temperatures have changed from a relatively cold period to a comparatively warm period. The time series of most annual and seasonal air and soil temperatures did not show any sudden changes. Abrupt changes of the annual air temperature and soil temperature at $320 \mathrm{~cm}$ depth occurred in 1997 and 2005, respectively. Air temperature in spring and soil temperature at $320 \mathrm{~cm}$ depth in summer showed abrupt changes in 1996 and 2005, respectively.

(5) Seasonally, the years of anomalous air temperature and soil temperatures at depths of 0,20 , and $80 \mathrm{~cm}$ were consistent, but they were inconsistent with soil temperature at $320 \mathrm{~cm}$ depth in winter 2012. Annually, the air temperature and soil temperature at $0 \mathrm{~cm}$ depth were anomalously high in 2007, whereas the soil temperatures at depths of 20 and $80 \mathrm{~cm}$ were anomalously high in 2017. In $2008,2009,2017$, and 2018, the soil temperature at $320 \mathrm{~cm}$ depth was anomalously high.

\section{Data Availability}

The daily air temperature data and soil temperature data at depths of $0,20,80$ and $320 \mathrm{~cm}(1960-2018)$ used to support the findings of this study were accessed from http://data. $\mathrm{cma} . \mathrm{cn} /$ under account and therefore cannot be made freely available. All other data are available from the authors upon reasonable request.

\section{Conflicts of Interest}

The authors declare that there are no conflicts of interest regarding the publication of this paper. 


\section{Acknowledgments}

This study was supported by the Jiangxi Meteorological Bureau and Jiangxi Eco-Meteorological Center and a bilateral cooperation project between the Natural Science Foundation of China and the Pakistan Science Foundation (41661144027). The CMA Climate Change Science Fund (CCSF (201722 and 201810)) provides a policy-oriented training course for $\mathrm{PhD}$ students. The authors are thankful for the support of the High-Level Talent Recruitment Program of the Nanjing University of Information Science and Technology (NUIST). The authors thank James Buxton MSc from Liwen Bianji, Edanz Group China (http://www. liwenbianji.cn./ac), for editing the English text of this manuscript.

\section{References}

[1] C. W. Team, R. K. Pachauri, and L. A. Meyer, "IPCC climate change 2014: synthesis report summary for policymakers," in Contribution of Working Groups I, II, and III to the Fifth Assessment Report of the Intergovernmental Panel on Climate Change, Cambridge University Press, Cambridge, UK, 2014.

[2] R.-Y. Lu and R.-D. Chen, "A review of recent studies on extreme heat in China," Atmospheric and Oceanic Science Letters, vol. 9, no. 2, pp. 114-121, 2016.

[3] L. W. Zhang, R. C. Yu, Z. L. Ding et al., Third National Assessment Report on Climate Change, Science Press, Beijing, China, 2015.

[4] Y. Zhang and W. Y. Chen, "Soil temperature in Canada during the twentieth century: complex responses to atmospheric climate change," Journal of Geophysical Research, vol. 110, no. D3, Article ID D03112, 2005.

[5] F. E. Nelson, “(Un) frozen in time," Science, vol. 299, no. 5613, pp. 1673-1675, 2003.

[6] F. E. Nelson, O. A. Anisimov, and N. I. Shiklomanov, "Subsidence risk from thawing permafrost," Nature, vol. 410, no. 6831, pp. 889-890, 2001.

[7] M. L. Goulden, S. C. Wofsy, J. W. Harden et al., "Sensitivity of boreal forest carbon balance to soil thaw," Science, vol. 279, no. 5348, pp. 214-217, 1998.

[8] S. E. Trumbore, O. A. Chadwick, and R. Amundson, "Rapid exchange between soil carbon and atmospheric carbon dioxide driven by temperature change," Science, vol. 272, no. 5260, pp. 393-396, 1996.

[9] A. M. Garcia-Suarez and C. J. Butler, "Soil temperatures at armagh observatory, northern Ireland, from 1904 to 2002," International Journal of Climatology, vol. 26, no. 8, pp. 1075-1089, 2006.

[10] B. Qian, E. G. Gregorich, S. Gameda, D. W. Hopkins, and X. L. Wang, "Observed soil temperature trends associated with climate change in Canada," Journal of Geophysical Research, vol. 116, no. D2, Article ID D02106, 2011.

[11] T. E. Osterkamp and V. E. Romanovsky, "Evidence for warming and thawing of discontinuous permafrost in Alaska," Permafrost and Periglacial Processes, vol. 10, no. 1, pp. 17-37, 1999.

[12] T. Zhang, R. G. Barry, D. Gilichinsky, S. S. Bykhovets, V. A. Sorokovikov, and J. Ye, "An amplified signal of climatic change in soil temperatures during the last century at Irkutsk, Russia," Climatic Change, vol. 49, no. 1-2, pp. 41-76, 2001.

[13] J. Du, C. Li, J. Liao et al., "Responses of climatic change on soil temperature at shallow layers in Lhasa from 1961 to 2005 (in
Chinese)," Meteorological Monthly, vol. 33, no. 10, pp. 61-67, 2007.

[14] C. Chen and G. S. Zhou, "Analysis on variation characteristics of air temperature and ground temperature in Guilin from 1961 to 2010," Acta Ecologica Sinica, vol. 33, no. 7, pp. 2043-2053, 2013.

[15] C. B. Fu and Q. Wang, "The definition and detection of the abrupt climate change," Scientia Atmospheric Sinica, vol. 16, no. 4, pp. 482-492, 1992.

[16] F. Y. Wei, Diagnostic and Predictive Technology in Modern Climatologic Statistics, Meteorological Press, Beijing, China, 1999.

[17] N. Oreskes, "The scientific consensus on climate change," Science, vol. 306, no. 5702, p. 1686, 2004.

[18] G. Jungqvist, S. K. Oni, C. Teutschbein, and M. N. Futter, "Effect of climate change on soil temperature in Swedish boreal forests," PLoS One, vol. 9, no. 4, Article ID e93957, 2014.

[19] M. Haei, M. G. Öquist, I. Buffam et al., "Cold winter soils enhance dissolved organic carbon concentrations in soil and stream water," Geophysical Research Letters, vol. 37, no. 8, pp. 162-169, 2010.

[20] E. S. Euskirchen, A. D. McGuire, D. W. Kicklighter et al., "Importance of recent shifts in soil thermal dynamics on growing season length, productivity, and carbon sequestration in terrestrial high-latitude ecosystems," Global Change Biology, vol. 12, no. 4, pp. 731-750, 2006.

[21] M. G. Öquist and H. Laudon, "Winter soil frost conditions in boreal forests control growing season soil $\mathrm{CO}_{2}$ concentration and its atmospheric exchange," Global Change Biology, vol. 14, no. 12, pp. 2839-2847, 2008.

[22] M. Haei, M. G. Öquist, J. Kreyling, U. Ilstedt, and H. Laudon, "Winter climate controls soil carbon dynamics during summer in boreal forests," Environmental Research Letters, vol. 8, no. 2, Article ID 024017, 2013.

[23] L. Rustad, J. Campbell, G. Marion et al., "A meta-analysis of the response of soil respiration, net nitrogen mineralization, and aboveground plant growth to experimental ecosystem warming," Oecologia, vol. 126, no. 4, pp. 543-562, 2001.

[24] T. Domisch, L. Finer, and T. Lehto, "Effects of soil temperature on biomass and carbohydrate allocation in Scots pine (Pinus sylvestris) seedlings at the beginning of the growing season," Tree Physiology, vol. 21, no. 7, pp. 465-472, 2001.

[25] J. M. Melillo, P. Steudler, J. Aber et al., "Soil warming and carbon-cycle feedbacks to the climate system," Science, vol. 298, no. 5601, pp. 2173-2176, 2002.

[26] M. Strömgren and S. Linder, "Effects of nutrition and soil warming on stemwood production in a boreal Norway spruce stand," Global Change Biology, vol. 8, no. 12, pp. 1194-1204, 2002.

[27] C. Chen and G. S. Zhou, "Characteristics of air temperature and ground temperature in alxa left banner from 1961 to 2010," Journal of Natural Resources, vol. 29, no. 1, pp. 92-103, 2014.

[28] H. F. Jiang, S. H. Liao, and A. Erike, "Statistical analysis on relationship between soil surface temperature and air temperature," Agricultural Meteorology, vol. 25, no. 3, pp. 1-4, 2004.

[29] T. H. Deng, G. A. Wang, J. L. Jiao et al., "Change analysis of grass temperature, ground temperature and air temperature," Meteorological and Environmental Sciences, vol. 32, no. 4, pp. 47-50, 2009.

[30] L. Z. Lu, H. J. Jin, X. L. Chang et al., "Interannual variations of the air temperature, surface temperature and shallow ground 
temperature along the China-Russia crude oil pipeline," Journal of Glaciology and Geocryology, vol. 32, no. 4, pp. 794-802, 2010.

[31] R. Fu, Z. G. Wei, J. Wen et al., "Analyses on characteristic of seasonal and interannual variation of difference between surface and air temperature (Ts-Ta) in arid region in northwest China," Plateau Meteorology, vol. 27, no. 4, pp. 844-851, 2008.

[32] R. Fu, Z. G. Wei, J. Wen et al., "Causes of variation of earth-air temperature difference in arid regions of northwest China," Journal of Desert Research, vol. 30, no. 6, pp. 1142-1149, 2010. 

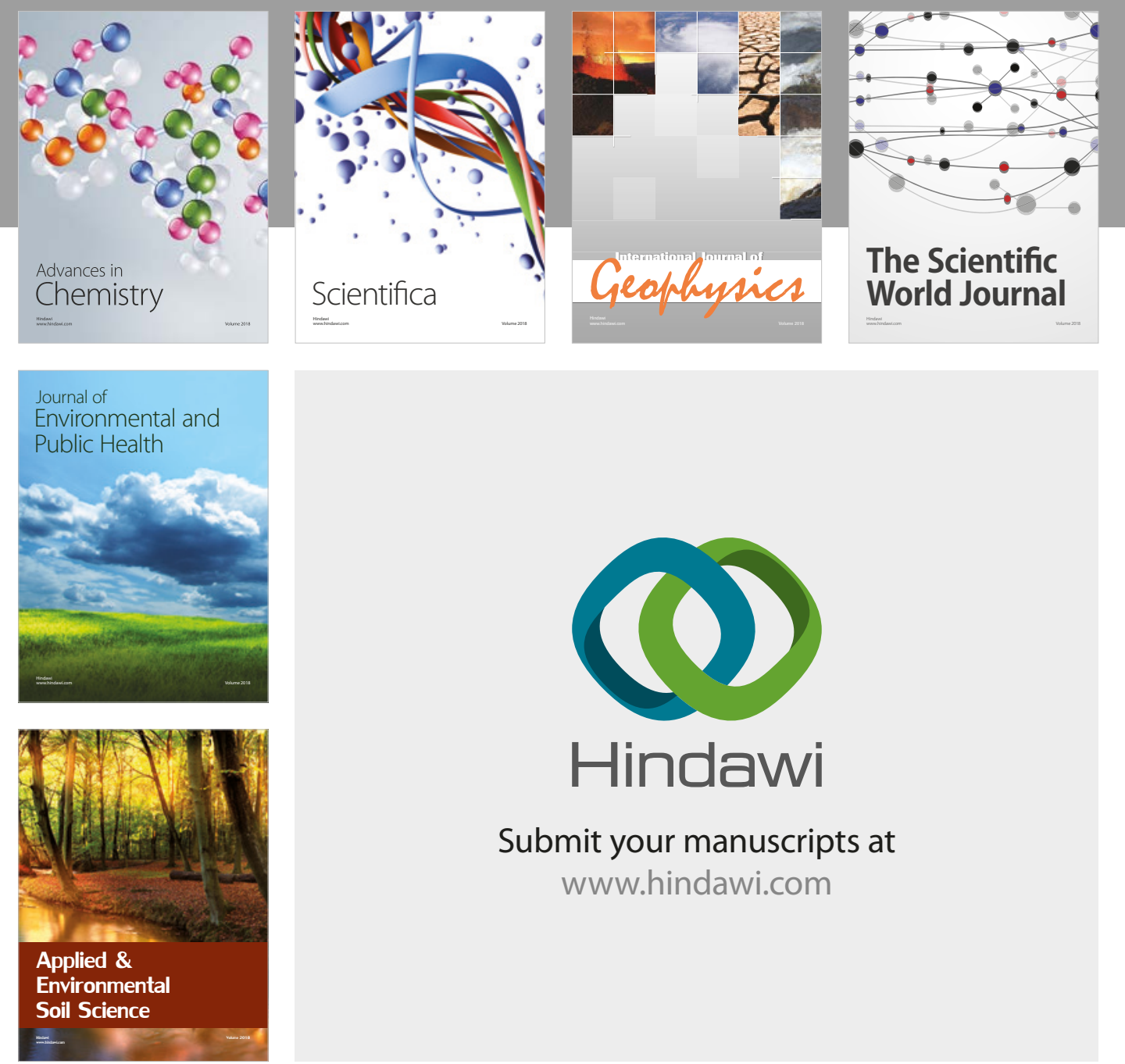

The Scientific

\section{World Journal}
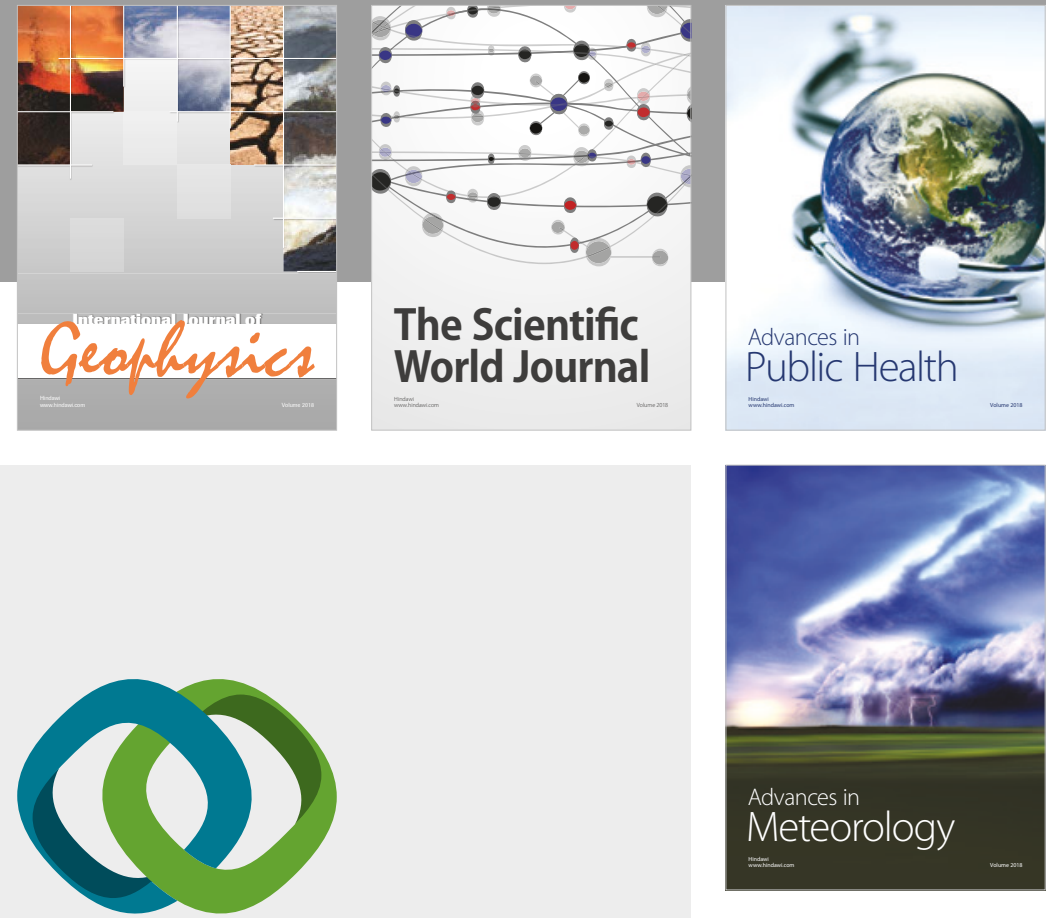

Advan

Public Health

\section{Hindawi}

Submit your manuscripts at

www.hindawi.com
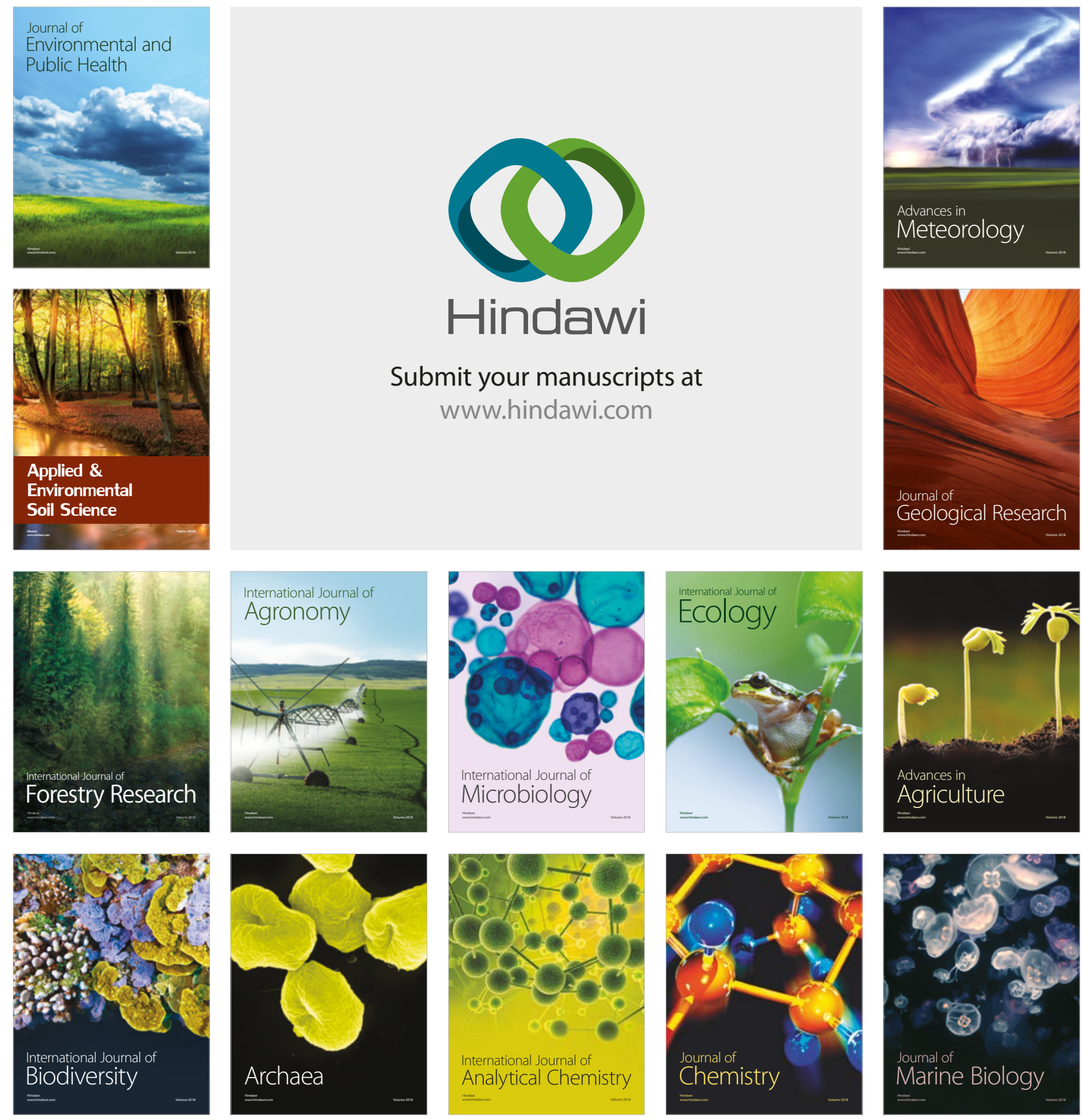